\title{
MODEL DISCOVERY LEARNING UNTUK MENINGKATKAN KETELITIAN DAN KETERAMPILAN MEMBACA SISWA
}

DESTA HARLITA, AGNES HERLINA DWI HADIYANTI, ALBERTUS SAPTORO

Universitas Sanata Dharma Yogyakarta, Indonesia

Email : desta.harlita@gmail.com

\begin{abstract}
ABSTRAK
Penelitian ini dilatar belakangi oleh Ketelitian dan keterampilan membaca menjadi kendala bagi siswa kelas II SD Kanisius Demangan Baru. Dimana hasil belajar sangat dipengaruhi dengan bagaimana guru memilih model penyampaian materi di kelas. Maka dari itu tujuan penelitian adalah memberikan referensi terkait model pembelajaran yang dalam penerapannya telah terbukti meningkatkan hasil belajar siswa. Jenis penelitian ini adalah Penelitian Tindakan Kelas. Penelitian ini dilakukan di SD Kanisius Demangan Baru. Teknik pengumpulan data menggunakan teknik observasi, wawancara, dan dokumentasi. Hasil penelitian menunjukkan bahwa penerapan model pembelajaran Discovery Learning dapat meningkatkan ketelitian dan keterampilan membaca. Hal ini ditunjukan dari data skor rata-rata awal ketelitian siswa yaitu 46,4, setelah akhir siklus I meningkat sebesar 58, dan siklus II sebesar 86 serta rata-rata awal keterampilan membaca siswa yaitu 51, setelah akhir siklus I meningkat sebesar 61, dan siklus II sebesar 82.
\end{abstract}

Kata kunci : ketelitian; keterampilan membaca; Discovery learning.

\section{PENDAHULUAN}

Discovery learning merupakan rangkaian kegiatan pembelajaran yang melibatkan secara maksimal seluruh kemampuan siswa untuk mencari dan menyelidiki secara sistematis, kritis, dan logis sehingga mereka dapat menemukan sendiri pengetahuan, sikap, dan keterampilan sebagai wujud adanya perubahan perilaku. Borthick dan Jones seperti yang dikutip Widyastuti (2015:35) mengemukakan dalam pembelajaran discovery, peserta belajar untuk mengenali masalah, solusi, mencari informasi yang relevan, mengembangkan strategi solusi, dan melaksanakan strategi yang dipilih. Dalam kolaborasi pembelajaran penemuan, peserta tenggelam dalam komunitas praktik, memecahkan masalah bersama - sama. Dalam Undang-Undang Nomor 20 Tahun 2012 tentang Sistem Pendidikan Nasional, Pasal 1 angka 1 menyatakan Kurikulum pendidikan yang dianut sekarang adalah Kurikulum 2013. Sistem kurikulum tersebut menuntut siswanya untuk menguasai tiga kemampuan yaitu pengetahuan, sikap, dan keterampilan. Salah satu bagian dari pengetahuan adalah pemahaman. Pemahaman merupakan proses dimana siswa sudah mengetahui dan mengerti pada materi yang sedang dipelajari. Selain pengetahuan yang berupa pemahaman, sikap siswa juga perlu dikembangkan. Salah satu contoh sikap yang harus dikuasai siswa adalah ketelitian. Ketelitian dapat diterapkan ke semua kegiatan yang dilakukan siswa termasuk membaca. Ketelitian dalam membaca diperlukan seorang siswa agar apa yang ingin ia sampaikan dalam bahasa tulis tersampaikan dengan tepat. Ketelitian dapat didefinisikan sebagai sikap untuk cermat dalam suatu hal agar terhindar dari kecerobohan (Sukmadinata, 2010: 220). Hal tersebut juga berlaku saat membaca. Ketelitian dalam membaca perlu diajarkan sejak sekolah dasar agar siswa tidak ceroboh saat membuat karya tulis. Pada penelitian ini ketelitian dan keterampilan memebaca siswa masih rendah karena dalam pelafalan, intonasi, kejelasan dan kelancaran membaca masih kurang. Sehingga perlu dilakukan penelitian tindakan kelas agar ketepatan dan kelancaran membaca lebih meningkat. Karena membaca salah satu kunci dalam memahami materi yang dipelajari. Sehingga dengan demikian, siswa tidak perlu dijelaskan berkali-kali untuk mendalami materi tersebut. Keterampilan berbahasa lisan maupun tulis memegang peranan penting dalam kehidupan manusia. Keterampilan berbahasa meliputi mendengarkan, berbicara, membaca, dan menulis. Keempat komponen ini merupakan satu kesatuan (Cahyani, 2017). Pada saat ini kita dituntut untuk 


\section{ELEMENTARY : Jurnal Inovasi Pendidikan Dasar Vol. 1 No. 3 Juli 2021, e-ISSN : 2774-7034 P-ISSN : 2774-8014}

menguasai ilmu pengetahuan dan teknologi. Salah satu tuntutan agar kita dapat menguasai ilmu pengetahuan dan teknologi adalah dengan membaca. Membaca merupakan salah satu ketrampilan berbahasa yang menduduki posisi dan peranan yang sangat penting dalam kontek kehidupan manusia (Rahim, 2015). Bahasa merupakan sarana yang sangat penting dalam kehidupan manusia karena bahasa merupakan alat untuk menyatakan pikiran dan perasaan kepada orang lain, untuk mengembangkan ekspresi, dan juga untuk mengembangkan kemampuan intelektual seseorang (Setiawan,2018).

Penelitian yang sebelumnya dilakukan oleh Yuliana (2018) mengenai penggunaan model pembelajaran Discovery Learning dalam peningkatan hasil belajar siswa di sekolah dasar. Metode tersebut dilaksanakan pada saat pembelajaran Bahasa Indonesia. Pemilihan mata pelajaran tersebut dikarenakan peneliti merasa didalam pembelajaran Bahasa Indonesia mencakup aspek mendengar, berbicara, mebaca, dan menulis. Sesuai dengan teori menurut Effendi (2012) Discovery learning merupakan suatu pembelajaran yang melibatkan peserta didik dalam pemecahan masalah untuk pengembangan pengetahuan dan ketrampilan. Namun dalam penelitian oleh Yuliana belum memuat aspek ketelitian dalam membaca pada siswa sekolah dasar. Padahal ketelitian membaca sangat berpengaruh terhadap peningkatan hasil belajar siswa. Membaca (dengan huruf kecil) di kelas rendah siswa sekolah dasar tujuannya adalah agar siswa memahami cara membaca dengan ejaan yang benar dan mengomunikasikan ide/pesan secara tertulis, materi pelajaran membaca dikelas rendah sekolah dasar disajikan secara bertahap dengan menggunakan pendekatan huruf, suku kata, kata-kata atau kalimat (Mustikowati, 2016). Penelitian ini berlangsung sampai 2 siklus. Hasil penelitian ini menunjukan adanya peningkatan ketelitian dan keterampilan membaca siswa kelas II yang dapat dilihat dari siklus I ke siklus II. Terdapat peningkatan pada Siklus I, walaupun belum mencapai target persentase $76 \%$. Sedangkan pada siklus II persentase mencapai skor tertinggi yakni 80\%. Penelitian ini diharapkan untuk mendapatkan teori baru tentang meningkatkan ketelitian dan ketrampilan membaca siswa dengan penerapan model Discovery learning. Hal ini penting dilakukan agar ketelitian dan keterampilan membaca siswa dapat meningkat dan siswa mampu membaca dengan baik. Penelitian ini berbeda dengan penelitian sebelumnya karena dalam penelitian ini, tidak hanya keterampilan membaca saja yang dapat naik secara siknifikan namun juga ketelitian siswa dalam membaca juga mengalami kenaikan yang baik seperti siswa dapat menyuarakan kalimat dengan lafal dan intonasi tepat serta menjawab soal bacaan dengan baik. Penelitian ini memiliki tujuan meningkatkan ketelitian dan keterampilan membaca siswa. (Ida: 2016) mengemukakan bahwa kelancaran dan ketepatan anak membaca pada tahap belajar membaca permulaan dipengaruhi oleh keaktifan dan kreativitas guru yang mengajar di kelas I SD. Pada umumnya di dalam pembelajaran membaca guru hanya menggunakan buku paket tanpa menggunakan media dalam pembelajaran membaca sehingga siswa belajar dengan suasana yang monoton. Guru tidak memberikan repetisi kepada siswa yang belum dapat membaca hal ini dikarenakan guru berburu cepat untuk menyelesaikan materi sehingga siswa merasa bingung dengan barisan huruf-huruf yang dilihatnya dan membuat siswa tidak bersemangat dalam belajar membaca (Fahrurrozi, 2016). Meningkatkan intensitas belajar membaca, serta meningkatkan ketelitaian dan ketrampilan membaca siswa dengan penerapan model Discovery Learning sangatlah baik digunakan untuk memperbaiki kualitas membaca anak. Secara sederhana membaca di kelas 1 SD lebih ditekankan pada upaya anak "melek huruf". Artinya, mendidik anak agar anak dapat mengenali dan mengubah lambang-lambang tertulis menjadi bunyi-bunyi yang bermakna (Tjoe, 2013). Kadang-kadang menurunnya prestasi belajar siswa bukan disebabkan oleh ketidak mampuannya mengikuti pelajaran, melainkan oleh kemalasannya belajar mandiri melalui kegiatan aktif membaca. Seperti kita ketahui bahwa membaca adalah carayang paling efektif untuk belajar mandiri (Sari,2016). Oleh karena itu ketelitian dan keterampilan membaca sangatlah penting untuk ditingkatkan pada siswa sekolah dasar, karena dapat membentuk kemandirian siswa dalam 
pemecahan masalah dalam materi pelajaran yang sedang di hadapinya, sehingga materi tersebut tidak perlu banyak pengulangan.

\section{METODE PENELITIAN}

Penelitian ini dilaksanakan di SD Kanisius Demangan Baru. Jl Demangan Baru No 22, Demangan Baru, Caturtunggal, Depok Sleman Yogyakarta. Pada semester genal tahun ajaran 2020/2021. Subjek dalam penelitian ini adalah siswa Kelas II SD Kanisius Demangan Baru tahun ajaran 2020/2021 yang berjumlah 20 siswa dengan perincian 9 siswa laki-laki dan 11 siswa perempuan. Untuk mendapatkan data-data yang diperlukan dalam penelitian ini, digunakan tiga teknik pengumpulan data yaitu, pengamatan atau observasi, wawancara dan dokumentasi. Instrumen yang digunakan untuk mengumpulkan data dalam penelitian ini yaitu instrument non tes. Instrumen non tes pada penelitian ini menggunakan instrumen observasi dan wawancara. Instrumen dalam penelitian ini adalah lembar observasi, pedoman wawancara, dan dokumen berupa RPP dan Lembar Penilaian dan Evaluasi. Pada pratindakan untuk mengumpulkan data awal peneliti menggunakan instrument wawancara kepada guru kelas. Metode wawancara dalam penelitian ini bertujuan untuk mengklarifikasi dan melengkapi data yang telah diperoleh dalam observasi. Dengan demikian, peneliti bisa memperoleh gambaran yang luas mengenai kendala-kendala yang dihadapi guru. Peneliti juga menggunakan metode observasi serta lembar penilaian dan evaluasi guna mendapatkan data terkait variabel ketelitian. Serta menggunakan observasi untuk mendapat data terkait keterampilan membaca siswa. Sugiyono (2016: 9) mengemukakan bahwa Observasi digunakan untuk mengamati segala aktivitas dan tingkah laku selama kegiatan pembelajaran. Metode dokumentasi digunakan untuk memperoleh data yang bersumber pada tulisan, seperti buku, majalah, dokumen, peraturan-peraturan, dan sebagainya.

Dalam penelitian ini menggunakan teknik analisis data yang berbentuk deskriptif kualitatif yaitu untuk menentukan peningkatan proses belajar khususnya berbagai tindakan yang dilakukan guru. Guru atau peneliti mengumpulkan semua instrumen yang digunakan untuk mengumpulkan data kemudian dikelompokkan berdasarkan fokus masalah. Ketelitian dihitung menggunakan hasil penugasan yang dikerjakan oleh siswa saat pembelajaran berlangsung. Peningkatan ketelitian diketahui dengan mengitung hasil dari kondisi awal, siklus I dan siklus II. Keterampilan membaca dihitung menggunakan hasil penugasan yang dikerjakan oleh siswa saat pembelajaran berlangsung.

\section{HASIL PENELITIAN DAN PEMBAHASAN}

\section{a. Hasil Penelitian}

Hasil analisis data diperoleh berdasarkan hasil observasi terhadap kegiatan pembelajaran membaca dengan menggunakan model Discovery Learning yang dilakukan dalam dua siklus. Pembelajaran pada siklus I terdiri dari dua pertemuan dengan materi yang berbeda pada setiap pertemuan. Pada pertemuan pertama, siswa belajar tentang membaca tema pengalamanku menggunakan kartu huruf. Pada pertemuan kedua, siswa belajar tentang kosakata dan ungkapan tema pengalamanku dengan media pembelajaran yang digunakan yaitu video dan kartu huruf. Kegiatan pembelajaran pada setiap pertemuan dilakukan berdasarkan tiga tahap pembelajaran,yaitu tahap pendahuluan, tahap inti,dan tahap penutup.

Kegiatan pembelajaran yang dilakukan pada tahap pendahuluan,meliputi (1) guru memberi salam untuk membuka pelajaran, (2) guru mengajak siswa berdoa untuk mengawali pembelajaran, (3) guru melakukan mengecek kehadiran siswa, (4) guru mengajak siswa menyanyikan lagu sambil memperagakan gerak dalam lagu, (5) guru melakukan apersepsi dan (6) guru menyampaikan kompetensi yang akan dicapai dalam pembelajaran. Selanjutnya kegiatan pembelajaran yang dilakukan pada tahap inti meliputi (1) Guru menyajikan gambar/video kemudian Siswa mengidentifikasi gambar/video yang ditampilkan, (2) Siswa 
melakukan permainan dengan bantuan guru, (3) guru memberikan contoh sebuah kalimat yang dipilih berdasarkan bacaan pada pembelajaran melalui permainan, (4) guru menggunakan kartu huruf untuk memberikan contoh menguraikan kalimat menjadi kata, suku kata dan huruf dan merangkai kembali huruf menjadi suku kata, kata dan kalimat seperti semula, (5) setelah memberikan contoh, guru membantu dan membimbing siswa untuk menguraikan kalimat menjadi kata, suku kata dan huruf kemudian merangkai kembali huruf menjadi suku kata, kata dan kalimat seperti yang dicontohkan, dan (6) siswa latihan membaca bacaan yang sudah disediakan kemudian siswa mengerjakan lembar kerja siswa yang disediakan guru. Pada kegiatan penutup, guru bersama siswa melakukan refleksi terhadap pembelajaran, kemudian menyimpulkan materi pembelajaran. Setelah itu, guru memotivasi siswa untuk belajar membaca di rumah. Kegiatan pembelajaran diakhiri dengan doa dan salam.

Untuk mengungkapkan apakah ada peningkatan ketelitian dan keterampilan membaca, maka di akhir pembelajaran diadakan penilaian membaca dengan menggunakan pedoman membaca yang dikemukakan (Budiasih, 2001) yang telah dimodifikasi. Sehingga saat pembelajaran berlangsung siswa lebih aktif dan bersemangat dalam membaca. Dengan semangat tersebut mmebuat siswa lebih rajin dalam meningkatkan ketelitiannya. Sehingga pelafalan dan intonasi dalam membaca dapat terdengar lebih jelas dibanding pada saat pra penelitian. Berdasarkan pedoman tersebut ketelitian dan keterampilan membaca siswa sudah mulai meningkat. Untuk lebih jelasnya dapat dilihat tabel berikut.

Tabel 1. Peningkatan Ketelitian Siswa

\begin{tabular}{ccccc}
\hline Variabel & Indikator & \multicolumn{3}{c}{ Hasil Perolehan } \\
\cline { 3 - 5 } Ketelitian & $\begin{array}{c}\text { Rata-rata seluruh } \\
\text { ketelitian siswa }\end{array}$ & Pratindakan & Siklus 1 & Siklus II \\
\hline & & 46,4 & 58 & 86 \\
\hline
\end{tabular}

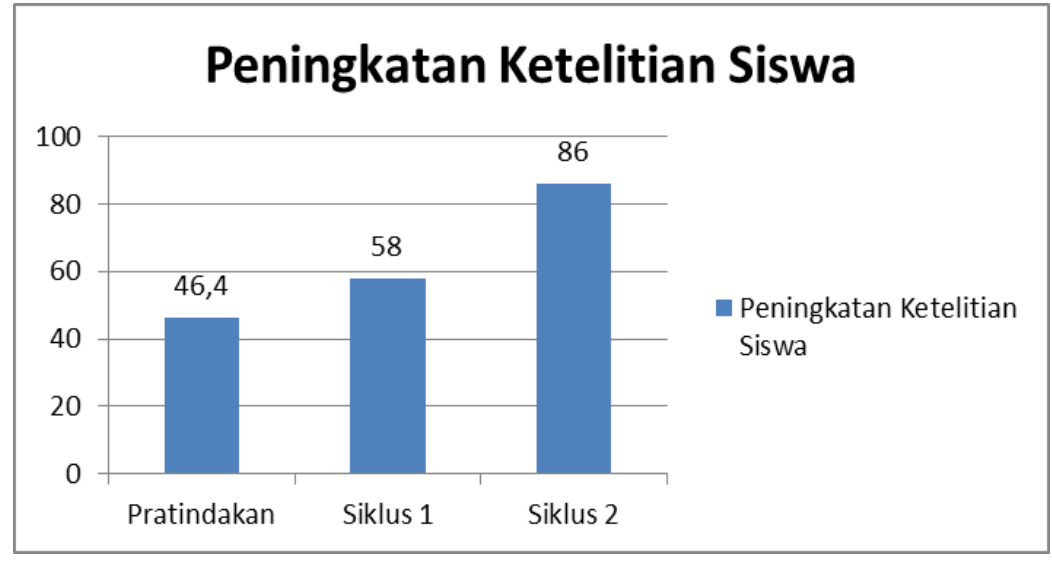

Gambar 1. Grafik Peningkatan Ketelitian Siswa

Berdasarkan tabel data tersebut menunjukkan adanya peningkatan nilai ketelitian membaca yaitu 46.4 pada pratindakan penelitian lalu meningkat menjadi 58 pada siklus 1 dan 86 pada siklus 2 . 
Tabel 2. Peningkatan Keterampilan Siswa

\begin{tabular}{ccccc}
\hline Variabel & Indikator & \multicolumn{3}{c}{ Hasil Perolehan } \\
\cline { 3 - 5 } Keterampilan & $\begin{array}{c}\text { Rata-rata seluruh } \\
\text { keterampilan } \\
\text { membaca siswa }\end{array}$ & 51 & Siklus 1 & Siklus II \\
\cline { 2 - 5 } & $\begin{array}{c}\text { Presentse jumlah } \\
\text { siswa yang mencapai } \\
\text { KKM }\end{array}$ & $35,7 \%$ & $53,5 \%$ & $89,2 \%$ \\
\hline
\end{tabular}

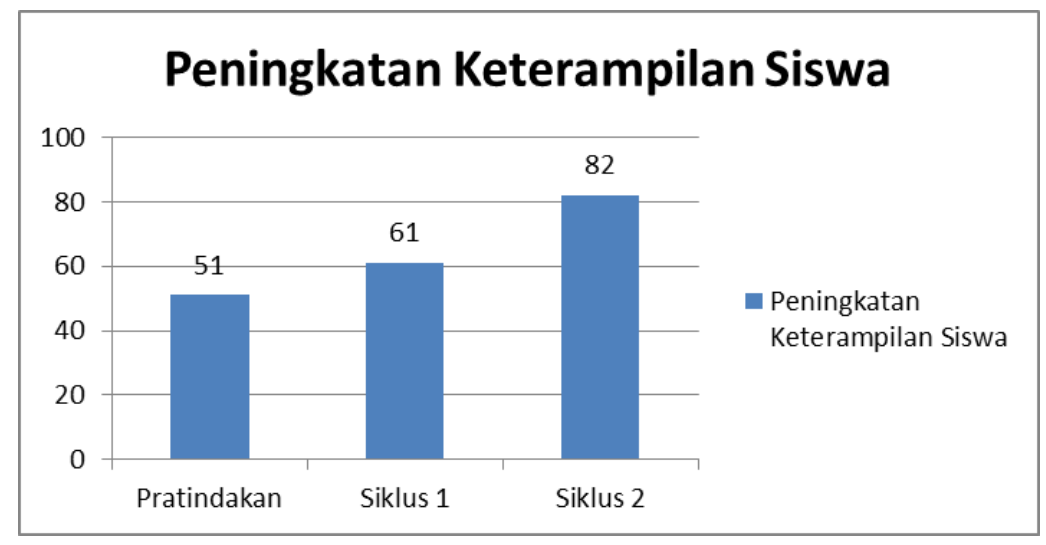

Gambar 2. Peningkatan Keterampilan Siswa

Berdasarkan tabel data tersebut menunjukkan adanya peningkatan nilai keterampilan membaca yaitu 51 pada pratindakan penelitian lalu meningkat menjadi 61 pada siklus 1 dan 82 pada siklus 2 .

2) Berdasarkan data di atas dapat disimpulkan bahwa penerapan model Discovery Learning dapat meningkatkan ketelitian dan keterampilan membaca. Sama hal nya penelitian yang dilakukan (Naitili, 2019) bahwa metode tersebut juga dapat meningkatan keterampilan membaca dan menulis siswa sekolah dasar di mana rata-rata persentase aktivitas siswa pada siklus I $60.33 \%$ berkualifikasi cukup, meningkat pada siklus II $75.42 \%$ berkualifikasi baik dan meningkat pada siklus III $82.42 \%$ berkualifikasi sangat baik.

Penelitian yang dilakukan ini juga memiliki hasil yang baik dimana hasil ketelitian penelitian pratindakan persentase siswa yang tuntas membaca hanya 46.4 dan hasil keterampilan hanya 51 tetapi pada saat dilakukan tindakan penerapan model Discovery Learning siklus I ketelitian membaca menjadi 58, sedangkan pada siklus II meningkat lagi menjadi 86 serta peningkatan nilai keterampilan membaca menjadi 61 pada siklus 1 dan 82 pada siklus II. Penetapan target ini berdasarkan pada pendapat Depdikbud (dalam Suwarto, 2013) menyatakan bahwa "suatu proses belajar dinilai mencapai ketuntasan belajar bila paling sedikit $85 \%$ dari jumlah siswa belajar mengajar mencapai taraf keberhasilan minimal".

\section{b. Pembahasan}

Setelah dilaksanakan penelitian mulai dari siklus I dan siklus II melalui penerapan model Discovery Learning untuk meningkatkan keterampilan membaca siswa kelas II SD Kanisius Demangan Baru dapat dijelaskan bahwa model Discovery Learning dapat meningkatkan ketelitian dan keterampilan membaca siswa. Selama kegiatan belajar mengajar dengan penerapan model Discovery Learning keterampilan dan ketelitian membaca siswa meningkat, pembelajaran juga lebih menarik karena guru menggunakan media seperti berbagai macam gambar, kartu huruf, kartu kata dan kartu kalimat. Dengan bantuan gambar dan bahan bacaan diambil dari bahasa sehari-hari 
yang sudah dikenal siswa ternyata dapat mempermudah siswa membaca, tepat dalam menyuarakan tulisan, intonasi, dan dapat memahami makna kata. Siswa juga bisa manganalisis kalimat menjadi kata, suku kata, huruf dengan menggunakan kartu-kartu yang dibagikan guru.

Pelaksanaan untuk meningkatkan kemampuan membaca pada subjek dilakukan dengan berkolaborasi antara peneliti dan guru kelas. Upaya peningkatan membaca pada subjek dengan menerapkan model Discovery Learnig. Model Discovery Learning bertujuan agar siswa terangsang oleh tugas, dan aktif mencari serta meneliti pemecahan masalah itu sendiri, mencari sumber dan belajar bersama di dalam kelompok. Diharapkan juga siswa mampu mengemukakan pendapatnya, berdebat, menyanggah, dan memperhatikan pendapatnya, menumbuhkan sikap obyektif, jujur, hasrat ingin tahu, terbuka dan lain sebagainya (Roestiyah, 2018:76). Aktivitas dengan menggunakan model Discovery Learning menunjukkan adanya peningkatan pada partisipasi anak dan kinerja guru. Hal ini sesuai dengan pendapat Sanjaya (2018: 210), bahwa media memiliki kontribusi yang sangat penting terhadap proses pembelajaran.

Hasil tes membaca siswa kelas II SD Kanisius Demangan Baru setelah dilaksanakan pembelajaran dengan menerapkan model Discovery Learning terus mengalami peningkatan dan menunjukkan keefektifan. Ketelitian pada siklus I dan II menunjukkan peningkatan daripada kondisi awal. Pernyataan tersebut dapat dibuktikan pada hasil penelitian yang menunjukan nilai rata-rata ketelitian membaca siswa kelas II SD Kanisius Demangan Baru ratarata pratindakan menunjukkan hasil 46,4. kemudian pada siklus I meningkat menjadi 58. Berdasarkan skala penilaian yang dikembangkan Arikunto (2016: 245) berada pada kategori “cukup" yakni berada pada rentang 56-65. Peningkatan ketelitian membaca ditandai dengan nilai ratarata siklus II sebesar 86 berada pada kategori "baik" serta rata-rata ketuntasan keterampilan membaca menunjukkan adanya peningkatan yaitu 51 meningkat menjadi 61 pada siklus I. Kemudian pada siklus II, rata-rata yang dihasilkan menjadi 82. Presentase siswa yang mencapai KKM pada siklus I sebesar 53,5\% kemudian meningkat menjadi 89,2\% pada siklus II. Berdasarkan hasil penelitian di atas, terbukti bahwa penerapan model Discovery Learning ini dinilai berhasil dan dapat meningkatkan ketelitian dan keterampilan membaca pada mata pelajaran bahasa Indonesia siswa kelas II SD Kanisius Demangan Baru. Berdasarkan hasil evaluasi yang dilakukan, masih ada siswa yang belum tuntas dalam keterampilan membaca, yakni belum mendapat nilai lebih dari 65, hal ini disebabkan kerena banyak hal mempengaruhi keterampilan membaca.

Penelitian ini juga didukung oleh beberapa penelitian yang telah dilakukan sebelumnya yang relevan yaitu Kasmini (2021) dengan hasil penelitian menunjukan model Discovery Learning dapat meningkatkan hasil belajar IPA di Sekolah Dasar Banda Aceh. Selanjutnya hasil penelitian yang dilakukan oleh Yeny (2020) menunjukkan bahwa melengkapi cerita juga dapat meningkatan keterampilan membaca permulaan.

\section{PENUTUP}

Model Pembelajaran Discovery Learning yang diterapkan pada pelaksanaan pembelajaran siswa kelas II SD Kanisius Demangan Baru, dapat meningkatkan ketelitian dan keterampilan membaca, Pada pratindakan nilai rata-rata ketelitian adalah 46,4 dan keterampilan 51. Pasca tindakan siklus I diperoleh nilai rata-rata ketelitian meningkat menjadi 58 dan siklus II menjadi 86 serta nilai rata-rata keterampilan membaca siklus I meningkat menjadi 61 dan sikus II menjadi 82. Pada penelitian ini peningkatan ketelitian dan keterampilan membaca dengan penerapan model Discovery Learning dapat dicapai maksimal.

Berdasarkan hasil penelitian dan pembahasan dapat disimpulkan bahwa kemampuan membaca pada anak berkesulitan membaca dapat meningkat dengan diterapkannya model pembelajaran Discovery Learning. Hal ini dibuktikan dengan adanya peningkatan pada hasil tes 
membaca pra tindakan, pasca tindakan I, dan pasca tindakan siklusII. Oleh karena itu pemberian tindakan dapat dihentikan.

\section{DAFTAR PUSTAKA}

Arikunto, S. (2016). Dasar-dasar Evaluasi Pendidikan. Jakarta: PT Bumi Aksara.

Budiasih, D. Z. (2001). Pendidikan Bahasa dan Sastra Indonesia di Kelas Rendah. Jakarta: Departemen Pendidikan dan Kebudayaan.

Cahyani, H. D. (2017). Kemampuan Bahasa Indonesia di SD. Bandung: UPI Press.

Depdikbud. (2012). Undang-undang No 20 tahun 2012 tentang sisdiknas. Jakarta: Depdikbud.

Effendi, L. A. (2012). Pembelajaran Bahasa indonesia menggunakan model Discovery learning guna meningkatkan pemecahan masalah. Jurnal Penelitian, 2.

Fahrurrozi. (2016). Pembelajaran Membaca Permulaan di Sekolah Dasar. Jurnal Ilmiah PGSD Vol. X No.2 Oktober.

Kasmini, L. (2021). Peningkatan Hasil Belajar IPA Melalui Implementasi Model Pembelajaran Discovery Learning di Sekolah Dasar Kota Banda Aceh. Jurnal Bidang Pendidikan Dasar.

Mustikowati, D. (2016). Meningkatkan Semangat dan Menulis Siswa Sekolah Dasar dengan Permainan Kata Bersambut. BRILIANT: Jurnal Riset dan Konseptual, 1(1), 16-23.

Naitili, C. A. (2019). Penerapan Metode Struktural Analtik Sintentik Untuk Meningkatkan Ketrampilan Menulis Siswa Sekolah Dasar. Jurnal Pendidikan, 1.

Rahim, F. (2005). Pembelajaran Membaca di Sekolah Dasar. Padang: Bumi Aksara.

Roestiyah. (2018). Strategi Belajar Mengajar. Jakarta: Rineka Cipta.

Sanjaya, W. (2009). Penelitian Tindakan Kelas. Jakarta: Kencana Prenada Media Group.

Sari, A. (2016). Pentingnya Ketrampilan Mendengar Dalam Menciptakan Komunikasi Yang efektif . Jurnal EduTech. Vol 2: (1).

Setiawan, D. (218). Penilaian AuthentikAssesment Guru pada Pembelajaran Bahasa Indonesia Sekolah Dasar. Jurnal Bidang Pendidikan Dasar (JBPD), Vol. 2No. 1Januari 2018, 95.

Sugiyono. (2016). Metode Penelitian Kuantitatif, Kualitatatif dan R\&D. Bandung: Alfabeta.

Sukmadinata, N. S. (2010). Metode Penelitian Pendidikan. Bandung: PT Remaja Rosdakarya.

Suwarto. (2013). Belajar tuntas, miskonsepsi, dan kesulitan belajar . Jurnal Pendidikan, 22 (1), 8596.

Tjoe, J. (2013). Peningkatan Kemampuan Membaca Permulaan Melalui Pemanfaatan Multimedia. Jurnal Pendidikan Usia Dini,7(1).

Widyastuti, E. S. (2015). Penerapan Model Pembelajaran Discovery Learning Pada Materi Konsep Ilmu Ekonomi. Prosiding Seminar Nasional, 35.

Yeny. (2020). Upaya Meningkatkan Keterampilan Menulis Permulaan dalam Melengkapi Cerita Rumpang Menggunakan Media Gambar dan Papan Bergaris. Pena Ilmiah, 1(1), 761-770.

Yuliana, N. (2018). Penggunaan Model Pembelajaran Discovery Learning Dalam Meningkatkan Hasil Belajar Siswa Sekolah Dasar. Jurnal Ilmiah Pendidikan dan Pembelajaran , 1 